\title{
Total Structural Elucidation of Erlotinib and Gefitinib by Mainly 2D-Rotating Frame Overhauser Effect Spectroscopy (2D ROESY NMR)
}

\author{
CIGDEM KARAASLAN ${ }^{1}$ and HAKAN GÖKER ${ }^{1,2^{*}}$
}

${ }^{1}$ Department of Pharmaceutical Chemistry, Faculty of Pharmacy, Ankara University, Turkey

${ }^{2}$ Central Instrumental Analysis Laboratory, Faculty of Pharmacy, Ankara University 06100 Tandogan, Ankara-Turkey

goker@ankara.edu.tr

Received 19 October 2016 / Accepted 7 Novembe 2016

\begin{abstract}
Erlotinib $\mathrm{HCl}$ (Tarceva®) and Gefitinib (Iressa $\left.{ }^{\circledR}\right)$ are well known anticancer drugs, which are used in the treatment of several chemoresistant cancer. Their total structural assignments of Erlotinib, Erlotinib $\mathrm{HCl}$ and Gefitinib have been achieved by using 2D-NMR experiments, including DEPT, COSY, ROESY, HSQC and HMBC. ROESY experiment gives the best important data for their structural elucidation.
\end{abstract}

Keywords: Erlotinib, Erlotinib HCl, Gefitinib, DEPT, COSY, ROESY, HSQC, HMBC. ROESY

\section{Introduction}

Erlotinib $\mathrm{HCl}\left(\mathbf{1}, \operatorname{Tarceva}^{\circledR}\right)^{1}$ and Gefitinib (2, Iressa $\left.{ }^{\circledR}\right)^{2}$ 4-aminophenylquinazoline oral anticancer drugs inhibits the activity of the epidermal growth factor receptor (EGFR) as tyrosine kinase inhibitors. Both of them have been (Figure 1) launched forthe treatment of chemoresistant non-small cell lung(NSCLC) ${ }^{3}$. In addition, Erlotinib has been reported to be effective in the treatment of glioma, head and neck cancers, as well ${ }^{4}$. Gefitinib is the first EGFRtargeting agent registered as an anticancer drug in Japan and Australia.FDA approved Gefitinib and Erlotinib in 2003 and 2005, respectively. These kinase inhibitors have been widely evaluated in cancer clinical trials ${ }^{5}$.

2D NMR data of Erlotinib and Gefitinib have not been previously published, as far as we know. In this work, we performed a detailed 2D NMR study using COSY, DEPT, ${ }^{1} \mathrm{H}^{-13} \mathrm{C}$ correlated HSQC and HMBC and ROESY methods, leading to a full ${ }^{1} \mathrm{H}$ and ${ }^{13} \mathrm{C}$ signals assignments for Erlotinib and Gefitinib. The coupling constants $J$ were reported in Hertz and the differences in the peak splittings in different situations were discussed. 

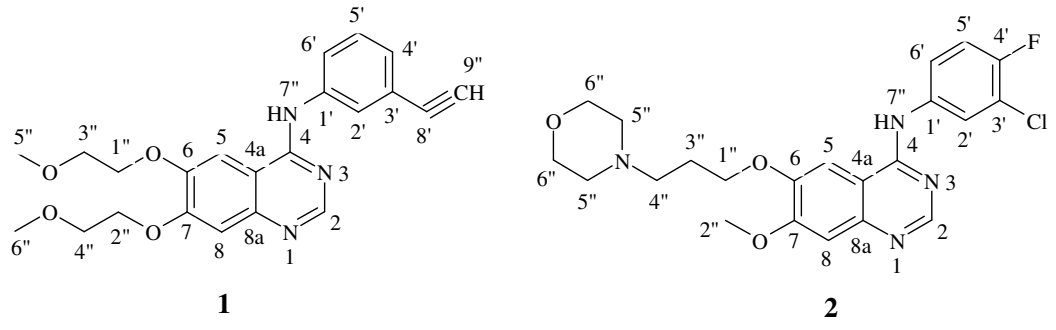

Figure 1. Structures of (1) Erlotinib and (2) Gefitinib

\section{Experimental}

Uncorrected melting points were measured on an Büchi B-540 capillary melting point apparatus. All NMR experiments were carried out by using VARIAN (AGILENT) MERCURY $400 \mathrm{MHz}$ (Varian, Palo Alto, CA) at a proton resonance frequency of 400.1779 and $100.6243 \mathrm{MHz}$ for carbon, equipped with a 5-mm broadband observed probe head. The NMR spectrum optimization was conducted by using Agilent VnmrJ version 3.2 revision A software and all parameters were set in it. The samples $(15 \mathrm{mg})$ were dissolved in $0.75 \mathrm{~mL}$ of DMSO- $d_{6}, \mathrm{CDCl}_{3}, \mathrm{CD}_{3} \mathrm{COCD}_{3}$ andCD $\mathrm{CDD}_{3} \mathrm{OD}$. The ${ }^{1} \mathrm{H}$ NMR experiments were traditionally carried out with TMS as an internal standart and its chemical shift set at $\delta=0 \mathrm{ppm}$, at r.t, unless stated otherwise. Pulse program for ${ }^{1} \mathrm{H}$ spectra was relax. delay $1 \mathrm{sec}$; pulse 45.0 degrees; 8 or 16 repetitions; acquisition time 2.559 secs; width $6402.0 \mathrm{~Hz}$. Pulse program for ${ }^{13} \mathrm{C}$ spectra was relax. delay $1 \mathrm{sec}$; pulse 45.0 degrees; 2000 repetitions; acquisition time 1.304 secs; width $21141.6 \mathrm{~Hz}$. The DEPT pulse program for carbon was relax. delay 1 secs; pulse 90.0 degrees; acquisition time 1.304 secs; width $21141.6 \mathrm{~Hz} ; 64$ repetitions. The HMBC pulse program for proton-carbon was relax. delay $1 \mathrm{secs}$; acquisition time 0.15 secs; width 6402.0 Hz; 2D width $21633.3 \mathrm{~Hz} ; 8$ repetitions; 2x256 increments. The HSQC pulse program for proton-carbon was relax. delay 1 secs; acquisition time 0.15 secs; width $6402.0 \mathrm{~Hz}$; 2D width $17105.0 \mathrm{~Hz} ; 8$ repetitions; $2 \times 256$ increments. The NOESY pulse program for proton was relax. delay 1 secs; acquisition time 0.15 secs; width $4046.9 \mathrm{~Hz}$; 2D width $4046.9 \mathrm{~Hz} ; 8$ repetitions; $2 \times 200$ increments. The ROESY pulse program for proton was relax. delay 1 secs; acquisition time 0.15 secs; width $4677.3 \mathrm{~Hz} ; 2 \mathrm{D}$ width $4677.3 \mathrm{~Hz} ; 8$ repetitions; $2 \times 200$ increments. The COSY pulse program for proton was relax. delay 1 secs; acquisition time 0.15 secs; width $4046.9 \mathrm{~Hz}$; 2D width $4046.9 \mathrm{~Hz}$; 4 repetitions; 128 increments.LC-MS coupled with positive (ESI+) Electro Spray method was used to determine molecular weight of the samples. The HPLC of LC/MS was carried out on a column XTerra ${ }^{\circledR}$ MS C-18 (4.6x250 mm, $5 \mu \mathrm{m}$ ) with $\mathrm{H}_{2} \mathrm{O}: \mathrm{CH}_{3} \mathrm{CN}: \mathrm{MeOH}: 0.1 \% \mathrm{HCOOH}$ in $\mathrm{CH}_{3} \mathrm{CN}(45: 35: 10: 10)$ with $0.5 \mathrm{~mL} / \mathrm{min}$ flow rate as mobile phase. The eluate was monitored by a photo-diode array detector at $254 \mathrm{~nm}$. The analytical condition of mass was as follows : capillary voltage : 3.11 $\mathrm{kV}$, cone voltage : $29 \mathrm{~V}$, source temperature : $100{ }^{\circ} \mathrm{C}:$ desolvation temperature : $300{ }^{\circ} \mathrm{C}$. Elemental analyses were performed by Leco CHNS-932.

$\mathrm{N}$-(3-Ethynylphenyl)-6,7-bis(2-methoxyethoxy)quinazolin-4-amine, Erlotinib (1)HCl

White colored powder, $\mathrm{mp} 232-235^{\circ} \mathrm{C}$, ESI-MS $(\mathrm{m} / \mathrm{z}): 394.5[\mathrm{M}+\mathrm{H}, 100 \%]+;$ Anal.Cald. for $\mathrm{C}_{22} \mathrm{H}_{23} \mathrm{~N}_{3} \mathrm{O}_{4} \cdot \mathrm{HCl}$ : C, 61.46; H, 5.63; N, $9.77 \%$; Found C, 61.33; H,5.56 ; N, 9.85. ${ }^{1} \mathbf{H}$ NMR $\left(\mathrm{CD}_{3} \mathrm{OD}\right) \delta \mathrm{ppm}(\mathrm{J}, \mathrm{Hz})$ at $34{ }^{\circ} \mathrm{C}: 3.46(\mathrm{~s}, 3 \mathrm{H}, \mathrm{H}-6 "), 3.47(\mathrm{~s}, 3 \mathrm{H}, \mathrm{H}-5 "), 3.57(\mathrm{~s}, 1 \mathrm{H}, \mathrm{H}-9 ")$, 3.87(m,4H,H,3",4"), 4.39(m,4H,H-2",1"), 7.27(s,1H,H-8), 7.41-7.43(dt,1H,J $=6.4$ Hzand $\left.\mathbf{J}_{m}=2.4 \mathrm{~Hz}, \mathrm{H}^{\prime} 4^{\prime}\right), \quad 7.45\left(\mathrm{t}, 1 \mathrm{H}, \mathrm{J}_{o}=7.6 \mathrm{~Hz}, \mathrm{H}^{\prime} 5^{\prime}\right), \quad 7.71\left(\mathrm{dt}, 1 \mathrm{H}, \mathrm{J}_{o}=7.2 \mathrm{~Hz}\right.$ and $\left.\mathbf{J}_{m}=2 \mathrm{~Hz}, \mathrm{H}-6^{\prime}\right)$, 7.86(br.t, 1H,H-2'), 8.02(s,1H,H-5), 8.7(s,1H,H-2), NH(unobservable). 


\section{N-(3-Ethynylphenyl)-6,7-bis(2-methoxyethoxy)quinazolin-4-amine,Erlotinib (1)}

$10 \mathrm{~mL}$ of $5 \% \mathrm{~K}_{2} \mathrm{CO}_{3}$ solution was added to the mixture of $0.25 \mathrm{~g}$ Erlotinib $\mathrm{HCl}$ in $15 \mathrm{~mL}$ of $33 \% \mathrm{MeOH}-\mathrm{HOH}$ and well stirred for $30 \mathrm{mins}$, the mixture was acidified with acetic acid, precipitate was filtered and washed with water and crystallized from $\mathrm{MeOH}$, white colored crystals, mp 159-161 ${ }^{\circ} \mathrm{C}$, ESI-MS $(\mathrm{m} / \mathrm{z}): 394.5[\mathrm{M}+\mathrm{H}, 100 \%]+$, Anal.Cald. for $\mathrm{C}_{22} \mathrm{H}_{23} \mathrm{~N}_{3} \mathrm{O}_{4}: \mathrm{C}$, 67.16; H, 5.89; N,10.68 \%, Found C, $66.96 ; \mathrm{H}, 5.57 ; \mathrm{N}, 10.66 .{ }^{1} \mathrm{H}-\mathrm{NMR}\left(\mathrm{CD}_{3} \mathrm{COCD}_{3}\right) \delta \mathrm{ppm}$ $(J, \mathrm{~Hz}): \quad 3.41(\mathrm{~s}, 3 \mathrm{H}, \mathrm{H}-6 "), \quad 3.42(\mathrm{~s}, 3 \mathrm{H}, \mathrm{H}-5 "), 3.66(\mathrm{~s}, 1 \mathrm{H}, \mathrm{H}-9 "), \quad 3.78-3.81(\mathrm{~m}, 2 \mathrm{H}, \mathrm{H}, 4 "), 3.82-$ 3.85(m,2H,H,3"), 4.27-4.29(m,2H,H-2"), 4.33-4.35(m,2H,H-1"), 7.21(dt,1H, $\mathrm{J}_{o}=7.6 \mathrm{~Hz}$ and $\left.\mathrm{J}_{m}=1.2 \quad \mathrm{~Hz}, \mathrm{H}_{-} 4^{\prime}\right), \quad 7.25(\mathrm{~s}, 1 \mathrm{H}, \mathrm{H}-8), \quad 7.37\left(\mathrm{t}, 1 \mathrm{H}, \quad \mathrm{J}_{o}=7.6 \quad \mathrm{~Hz}, \mathrm{H}-5{ }^{\prime}\right), \quad 7.76(\mathrm{~s}, 1 \mathrm{H}, \mathrm{H}-5), \quad 7.90-$ 7.93(m,1H,H-6'), 8.11-8.13(m,1H,H-2'), 8.55(s,1H,H-2), 8.89(br.s,1H,H-7'). ${ }^{1} \mathrm{H}$ NMR $\left(\mathrm{CDCl}_{3}\right) \delta$ ppm (J, Hz): 3.08(s,1H,H-9"), 3.42(s,3H,H-6"), 3.44(s,3H,H-5"), 3.78-3.8(m,4H,H3",4"), 4.19-4.24(m,4H,H-1",2"), 7.17(s,1H,H-8), 7.21(s,1H,H-5), 7.25 (dt,1H, $\mathrm{J}_{0}=8$ Hzand $\left.\mathrm{J}_{m}=1.2 \mathrm{~Hz}, \mathrm{H}-4^{\prime}\right), 7.33\left(\mathrm{t}, 1 \mathrm{H}, \mathrm{J}_{o}=7.6 \mathrm{~Hz}, \mathrm{H}-5\right.$ '), 7.47(br.s,1H,H-7'), 7.74(dm,1H, $\mathrm{J}_{o}=7.6 \mathrm{~Hz}, \mathrm{H}-6$ '), $7.85\left(\mathrm{t}, 1 \mathrm{H}, \mathrm{J}_{m}=1.6 \mathrm{~Hz}, \mathrm{H}-2\right.$ '), 8.65(s,1H,H-2). COSY, ROESY, HSQC, HMBC, DEPT, ${ }^{13} \mathrm{C}$ NMR $\left(\mathrm{CDCl}_{3}\right): 156.23(C-4), 154.6(C-7), 153.59(\mathrm{CH}-2), 148.87(C-6), 147.58(C-8 \mathrm{a}), 138.81\left(C-1^{\prime}\right)$, 128.99(CH-5'), 127.74(CH-4'), 125.0(CH-2'),122.83(C-3'), 122.25(CH-6'), 109.12(C-4a), 108.8(CH-8), 102.54(CH-5), 83.34(C-8”), 77.44(CH-9"), 70.98( $\mathrm{CH}_{2}-3$ "), $70.41\left(\mathrm{CH}_{2}-4 "\right)$, 69.24( $\mathrm{CH}_{2}-1$ "), 68.29( $\mathrm{CH}_{2}-2$ "), 59.3( $\mathrm{CH}_{3}-5$ "), 59.22( $\left.\mathrm{CH}_{3}-6 "\right)$.

N-(3-Chloro-4-fluorophenyl)-7-methoxy-6-(3-morpholin-4-yl-propoxy)quinazolin-4amine, Gefitinib (2)

White colored crystal, mp 195-197 ${ }^{\circ} \mathrm{C}$, ESI-MS $(\mathrm{m} / \mathrm{z})$ : 224(100\%), 447[M+H, 33\%], $449[\mathrm{M}+\mathrm{H}+2,10 \%]$; Anal.Cald. for $\mathrm{C}_{22} \mathrm{H}_{24} \mathrm{ClFN}_{4} \mathrm{O}_{3}$ : C, $59.13 ; \mathrm{H}, 5.41 ; \mathrm{N}, 12.54 \%$; Found C, 59.03; H,5.47; N, 12.76 .

\section{Results and Discussion}

It seems to be there is a mess about the previously published NMR data of Erlotinib and its $\mathrm{HCl}$ salt $^{6-19}$. There are several reasons for this confusion. For example, Erlotinib $\mathrm{HCl}$ should be the mixture of erlotinib base and its $\mathrm{HCl}$ salt, which we met to this situtation, with one of the commercially avaliable Erlotinib $\mathrm{HCl}$ sample and some of the chemical shift values changed substantially. Silver stabilize deuterated $\mathrm{CDCl}_{3}$ causes to yellow coloured precipitate, probably the reason of the reaction between the $\mathrm{Ag}$ and acetylene group, that is why, it cannot be used. Highly different melting points and colors are reported in lit ${ }^{6-19}$. Actually pure Erlotinib sample must be white. Yellow coloured samples should have some impurities. As a matter of course, highly different ${ }^{1} \mathrm{H}$ and ${ }^{13} \mathrm{C}$ NMR spectra (in DMSO- $d_{6}$ ) of Erlotinib $\mathrm{HCl}$ have been reported in literature ${ }^{6-16}$. Our ${ }^{1} \mathrm{H}$ NMR results are totally in agreement with literature ${ }^{6-11}$. Others should have some printing mistake, or e.g. there is a conflict between the NMR spectrum of the base and $\mathrm{HCl}$ salt of Erlotinib in literature ${ }^{12}$. On the other hand, ${ }^{1} \mathrm{H}$ NMR spectrum of Erlotinib base in $\mathrm{CDCl}_{3}$ were also reported in lit ${ }^{16-19}$, while our ${ }^{1} \mathrm{H}$ NMR result is totally consistent with literature ${ }^{12,16}$, in contrast is not equal within literature ${ }^{17,18}$. One more other confusion is here: Zhang et al., ${ }^{19}$ reported NMR values of Erlotinib base in $\mathrm{CDCl}_{3}$, instead of Erlotinib $\mathrm{HCl}$.We have tested that, it was impossible to run the ${ }^{1} \mathrm{H}$ NMR of Erlotinib $\mathrm{HCl}$ in $\mathrm{CDCl}_{3}$, since it has naturally no solubility. Our ${ }^{13} \mathrm{C}$ NMR result of Erlotinib $\mathrm{HCl}$ is in accordance with literature ${ }^{6,12}$. The ${ }^{13} \mathrm{C}$ NMR data in literature $^{13}$ was completely transferred from literature ${ }^{18}$ only with changing the name of deuterated solvent. Moreover, our ${ }^{13} \mathrm{C}$ NMR result is also highly different than literature ${ }^{18}$ for Erlotinib. 
Because of the bis 2-methoxyethoxy substitution at position 6 and 7 of Erlotinib $\mathrm{HCl}$, the NMR interpretation is almost impossible without 2D NMR data.At first, we investigated the effect of temperature on the chemical shift $\left({ }^{1} \mathrm{H} \mathrm{NMR}\right)$ values of Erlotinib $\mathrm{HCl}(15 \mathrm{mg}$ of sample, in $0.75 \mathrm{~mL}$ of DMSO- $d_{6}$ ) and noticed a chemical shift reversal towards low field for the proton at $\mathrm{C}-8$, on gradually increasing the temperature $\left(24-50{ }^{\circ} \mathrm{C}\right)$, the remaining aromatic protons have not been effected seriously by temperature changes (Figure 2). H-8 splitting patterns were not enough clear at $24^{\circ}, 41^{\circ}$ and $50^{\circ} \mathrm{C}$, due to that overlapping of the other aromatic peaks.
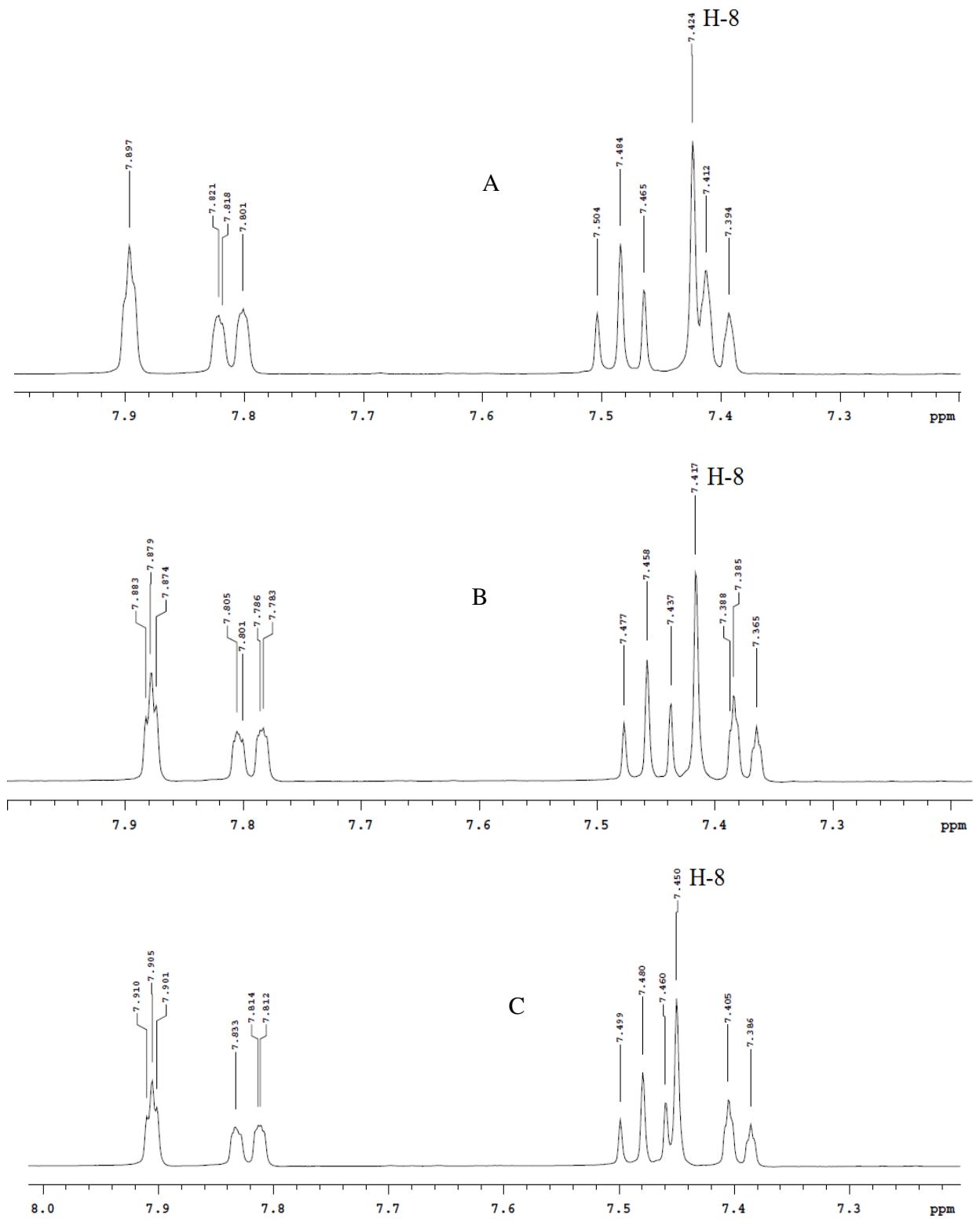


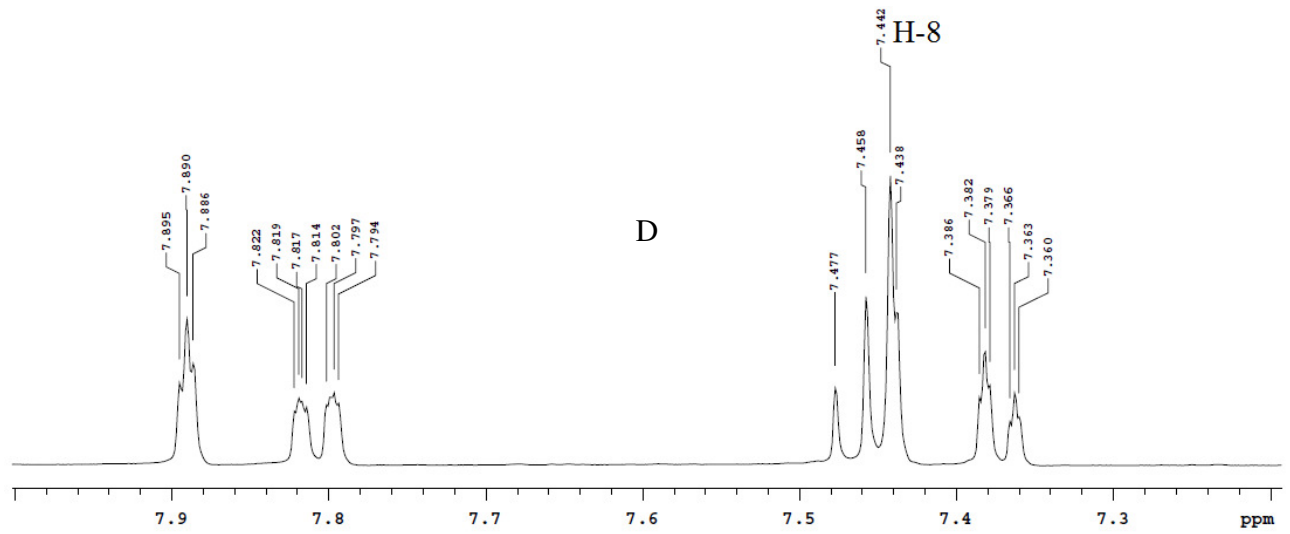

Figure 2. Effect of temperature on the chemical shift of the $\mathrm{H}-8$ proton of Erlotinib $\mathrm{HCl}$ in DMSO- $d_{6}$. A) $\left.24{ }^{\circ} \mathrm{C} \mathrm{B}\right) 34{ }^{\circ} \mathrm{C}$ C) $41{ }^{\circ} \mathrm{C}$ D) $50{ }^{\circ} \mathrm{C}$

In contrast, it appeared as a sharp singlet at $\delta 7.42 \mathrm{ppm}$ without overlapping at $34{ }^{\circ} \mathrm{C}$. In addition at this temperature, none of the protons seems to be overlapped, that is why, all of the further NMR experiments were run at $34{ }^{\circ} \mathrm{C}$. As it could be easily estimated that, the proton of $\mathrm{N}-\mathrm{H}$ (at position 7') observed as singlet and resonated at $\delta 11.6 \mathrm{ppm}$. First, we have attempted to run NOESY spectrum, in order to see whether there should be possible correlation between this anilino NH proton with $\mathrm{H}-5$ proton, which is one of the best close proton in space without neighbouring. Unfortunately, it was not possible to see this expected correlation contour by the NOESY spectrum. On the other hand, it was reported that ${ }^{20}$ ROESY experiment has been used for the structure elucidation of inclusion complex of Erlotinib with sulfobutyl ether- $\beta$-cyclodextrin, hencewe have also run the ROESY spectra. Actually, in the ROESY spectrum of Erlotinib $\mathrm{HCl}$ (Figure 3), the NH proton signal at $\delta 11.6$ ppm gives NOE with the peak at $\delta 8.50 \mathrm{ppm}$. Therefore the peak at $\delta 8.50 \mathrm{ppm}$ is due to H-5 (Table 1). Furthermore, this aromatic proton $\mathrm{H}-5$ show NOE with the proton at $\delta 4.41 \mathrm{ppm}$. Therefore, the signal at $\delta 4.41 \mathrm{ppm}$ is due to C-1" methylene protons. Similarly, the other methylene protons at C-2" can show NOE with $\mathrm{H}-8$. The methylene protons at $\delta 4.32 \mathrm{ppm}$ show NOE with the proton at $\delta 7.42 \mathrm{ppm}$. Therefore, the signal at $\delta 7.42 \mathrm{ppm}$ is due to $\mathrm{H}-8$. These last two assignments were seen in both of the NOESY and ROESY spectra of Erlotinib $\mathrm{HCl}$. In order to support these findings, same experiments have been done for Gefitinib which is no bis substitution on the benzene moiety, hence interpretation of Gefitinib is easier than Erlotinib. Our ${ }^{1} \mathrm{H}$ and ${ }^{13} \mathrm{C}$ NMR chemical shift and coupling constants data in DMSO- $d_{6}$ of Gefitinib are in good agreement with $\operatorname{lit}^{21}$. Same observations have been obtained in the ROESY spectrum of Gefitinib (Figure 4), the contour at $\delta 9.54$ and $\delta 7.80 \mathrm{ppm}$ indicated, the NOE of H-7": H-5 and the contour at $\delta 7.80$ and $\delta 4.18$ indicated, the NOE of H-5 : H-1", respectively. Also it was possible to see the NOE correlation between the H-8 and H-2" as in Erlotinib. The complete assignments of Gefitinib were also made using 1D and 2D NMR including COSY, ROESY, DEPT, HSQC and HMBC NMR in DMSO- $d_{6}$ and there was no unexpected situtation of the interpretation of Gefitinib (Table 2). In addition, virtual 3D conformational data of Erlotinib and Gefitinib also support these findings. (Figure 5) shows the molecular conformation of these compounds and depicts the numbering scheme with NOE effected hydrogen atoms. All of the obtained data from the ROESY spectra are in accordance with the $3 \mathrm{D}$ virtual conformation of Erlotinib and Gefitinib structures as it seen in Figrue 4. 
Table 1. ${ }^{1} \mathrm{H},{ }^{13} \mathrm{C}, \mathrm{COSY}, \mathrm{ROESY}, \mathrm{DEPT}, \mathrm{HSQC}$ and $\mathrm{HMBC}$ data of Erlotinib $\mathrm{HCl}$ and Erlotinib base

\begin{tabular}{|c|c|c|c|c|c|c|c|c|c|c|c|c|c|}
\hline \multicolumn{7}{|c|}{ Erlotınıb $\mathrm{HCl}$} & \multicolumn{7}{|c|}{ Erlotınıb Base } \\
\hline No & ${ }^{1} \mathrm{H} \delta$ & ${ }^{13} \mathrm{C} \delta, \mathrm{HSQC}$ & DEPT $^{*}$ & COSY & ROESY & HMBC & No & ${ }^{13} \mathrm{C} \delta$ & ${ }^{1} \mathrm{H} \delta, \mathrm{HSQC}$ & DEPT $^{*}$ & COSY & ROESY & HMBC \\
\hline 4 & 158.06 & & 0 & & & $\begin{array}{c}\text { H-2,5, } \\
\text { H-8(weak) }\end{array}$ & 4 & 156.10 & & 0 & & & $\begin{array}{c}\text { H-2,5,7" } \\
\text { H-8(weak) }\end{array}$ \\
\hline 7 & 155.61 & & 0 & & & H-5,8 & 7 & 153.65 & & 0 & & & H-5,8 \\
\hline 6 & 149.34 & & 0 & & & $\mathrm{H}-5,8$ & 2 & 152.75 & $8.49(\mathrm{~s}, 1 \mathrm{H})$ & 1 & & & -- \\
\hline 2 & 148.49 & $8.83(\mathrm{~s}, 1 \mathrm{H})$ & 1 & & & --- & 6 & 148.12 & & 0 & & & $\mathrm{H}-5,8$ \\
\hline $1^{\prime}$ & 137.25 & & 0 & & & H-5' & $8 \mathrm{a}$ & 146.97 & & 0 & & & $\begin{array}{c}\text { H, } 5,8 \\
\text { H-2(weak) }\end{array}$ \\
\hline $8 \mathrm{a}$ & 135.36 & & 0 & & & H-2,5,8 & $1^{\prime}$ & 139.82 & & 0 & & & H-5, \\
\hline $4^{\prime}$ & 129.18 & $\begin{array}{c}7.39(\mathrm{dt}, 1 \mathrm{H}, J=8, \\
J=1.2)\end{array}$ & 1 & H-5' & & H-2',6' & $5^{\prime}$ & 128.85 & $\begin{array}{c}7.39 \\
(\mathrm{t}, 1 \mathrm{H}, J=8)\end{array}$ & 1 & H-4',6' & & --- \\
\hline $5^{\prime}$ & 128.97 & 7.48(t,1H,J=8) & 1 & H-4',6' & & --- & $4^{\prime}$ & 126.32 & $\begin{array}{c}7.205 \\
(\mathrm{~d}, 1 \mathrm{H}, J=7.2)\end{array}$ & 1 & H-5' & & H-2' \\
\hline $2^{\prime}$ & 127.55 & 7.9(t,1H,J=1.2) & 1 & & & H-4',6' & $2^{\prime}$ & 124.74 & $\begin{array}{c}8.00 \\
(\mathrm{t}, 1 \mathrm{H}, J=1.6)\end{array}$ & 1 & & & H-4',6',7" \\
\hline $6^{\prime}$ & 125.25 & $\begin{array}{c}7.81 \\
(\mathrm{dm}, 1 \mathrm{H}, J=8)\end{array}$ & 1 & H-5' & & H-2', $4^{\prime}$ & $6^{\prime}$ & 122.54 & $\begin{array}{l}7.89(\mathrm{dd}, 1 \mathrm{H}, \\
\left.J_{o}=8, J_{m}=1.2\right)\end{array}$ & 1 & H-5' & & H-2', 4',7" \\
\hline $3^{\prime}$ & 121.91 & & 0 & & & H-9", 5' & $3^{\prime}$ & 121.74 & & 0 & & & H-5',9', \\
\hline $4 a$ & 107.32 & & 0 & & & H-8 & $4 a$ & 108.92 & & 0 & & & H-8 \\
\hline 5 & 105.29 & $8.50(\mathrm{~s}, 1 \mathrm{H})$ & 1 & & H-7",1" & $\ldots$ & 8 & 108.17 & $7.198(\mathrm{~s}, 1 \mathrm{H})$ & 1 & & H-2" & $\ldots$ \\
\hline 8 & 100.55 & 7.44(s,1H) & 1 & & H-2" & - - - & 5 & 103.14 & $7.83(\mathrm{~s}, 1 \mathrm{H})$ & 1 & & H-7", $1 "$ & - - - \\
\hline $8 "$ & 82.86 & & 0 & & & H-2', $4^{\prime}$ & $8 "$ & 83.53 & & 0 & & & H-2', $4^{\prime}$ \\
\hline $9^{\prime \prime}$ & 81.14 & $4.25(\mathrm{~s}, 1 \mathrm{H})$ & 1 & & & -- & 9" & 80.47 & 4.18(s,1H) & 1 & & & - \\
\hline $3 "$ & 69.86 & $3.79(\mathrm{~m}, 2 \mathrm{H})$ & 2 & H-1" & & H-5” & $3 "$ & 70.14 & $3.77(\mathrm{t}, 2 \mathrm{H}, J=4.8)$ & 2 & H-1" & & H-5” \\
\hline 4" & 69.70 & $3.77(\mathrm{~m}, 2 \mathrm{H})$ & 2 & H-2" & & H-6” & $4 "$ & 70.06 & $\begin{array}{c}3.73((\mathrm{t}, 2 \mathrm{H}, J= \\
4.8)\end{array}$ & 2 & H-2" & & H-6", \\
\hline $1 "$ & 69.09 & $4.41(\mathrm{t}, 2 \mathrm{H}, J=4.8)$ & 2 & H-3" & H-5 & --- & $1 "$ & 68.38 & $4.27(\mathrm{~m}, 2 \mathrm{H})$ & 2 & H-3" & $\mathrm{H}-5$ & --- \\
\hline $2^{\prime \prime}$ & 68.70 & $4.32(\mathrm{t}, 2 \mathrm{H}, J=4.4)$ & 2 & H-4" & $\mathrm{H}-8$ & -- & $2 "$ & 68.03 & $4.25(\mathrm{~m}, 2 \mathrm{H})$ & 2 & H-4" & $\mathrm{H}-8$ & -- \\
\hline $5 "$ & 58.34 & $3.365(\mathrm{~s}, 3 \mathrm{H})$ & 3 & & & H-3" & $5 "$ & 58.40 & $3.36(\mathrm{~s}, 3 \mathrm{H})$ & 3 & & & H-3" \\
\hline $6 "$ & 58.28 & $3.362(\mathrm{~s}, 3 \mathrm{H})$ & 3 & & & H-4" & 6" & 58.34 & $3.34(\mathrm{~s}, 3 \mathrm{H})$ & 3 & & & H-4" \\
\hline 7" & & $11.6(\mathrm{~s}, 1 \mathrm{H})$ & & & $\mathrm{H}-5$ & & 7" & & $9.45(\mathrm{~s}, 1 \mathrm{H}))$ & & & $\mathrm{H}-5$ & \\
\hline
\end{tabular}




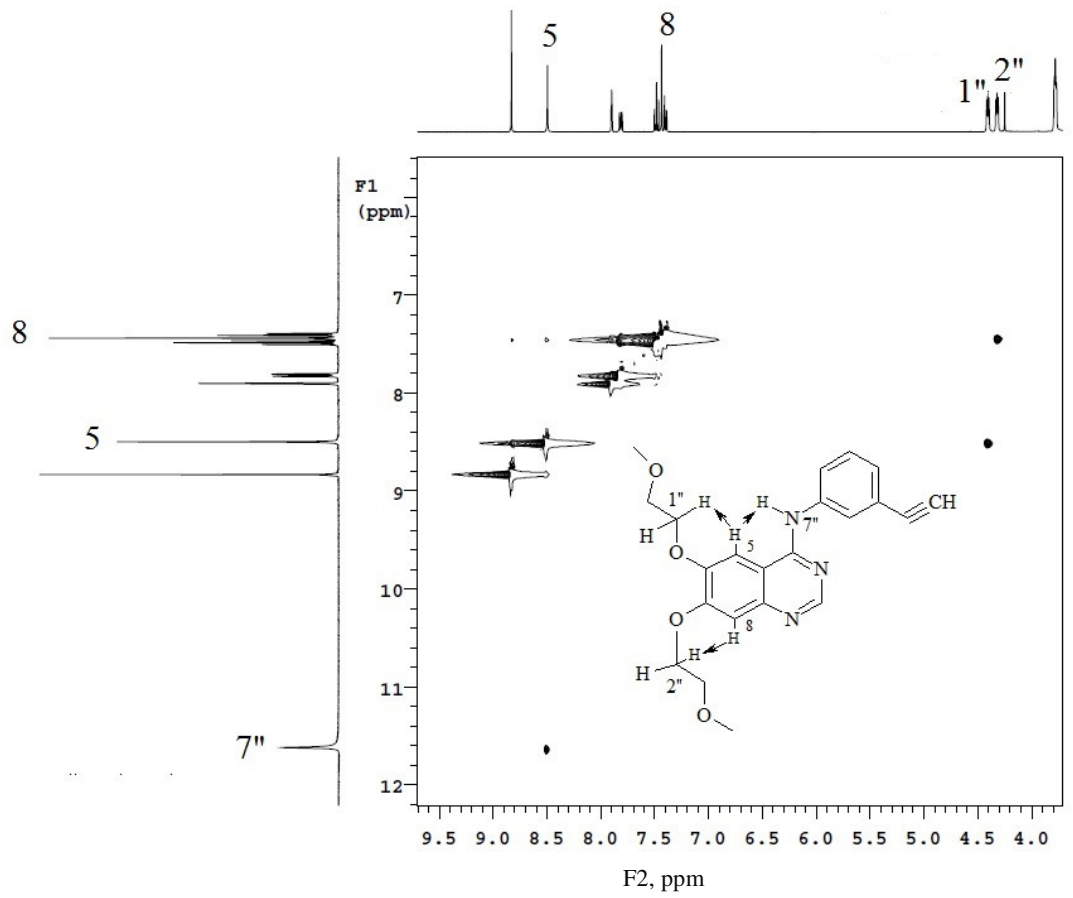

Figure 3. ROESY spectrum of Erlotinib $\mathrm{HCl}$ in DMSO- $d_{6}$

Table 2. ${ }^{1} \mathrm{H},{ }^{13} \mathrm{C}$, COSY, ROESY, DEPT, HSQC and HMBC data of Gefitinib

\begin{tabular}{|c|c|c|c|c|c|c|}
\hline No & ${ }^{13} \mathrm{C} \delta$ & ${ }^{1} \mathrm{H} \delta$, HSQC & DEPT & COSY & ROESY & HMBC \\
\hline 4 & 155.97 & & 0 & & & H-2,5,H-8(weak) \\
\hline 7 & 154.48 & & 0 & & & H-5, 8,2, \\
\hline $4^{\prime}$ & $153.1(J=240)$ & & 0 & & & $\mathrm{H}-2^{\prime}, 5^{\prime}, 6^{\prime}$ \\
\hline 2 & 152.56 & $8.50(\mathrm{~s}, 1 \mathrm{H})$ & 1 & & & - - \\
\hline 6 & 148.32 & & 0 & & & $\mathrm{H}-5,8,1^{\prime \prime}$ \\
\hline $8 a$ & 146.94 & & 0 & & & $\mathrm{H}-2,5,8$ \\
\hline $1^{\prime}$ & $136.79(J=2)$ & & 0 & & & H-2',5' \\
\hline $2^{\prime}$ & 123.45 & $8.12(\mathrm{dd}, 1 \mathrm{H}, J=7.2, J=2.4)$ & 1 & & & H-6 \\
\hline 6 ' & $122.28(J=7)$ & $7.81(\mathrm{~m}, 1 \mathrm{H})$ & 1 & $\mathrm{H}-5$ & & $\mathrm{H}-2$ \\
\hline 3 ' & $118.72(J=18.6)$ & & 0 & & & $\mathrm{H}-2^{\prime}, 5^{\prime}$ \\
\hline 5 , & $116.45(J=21)$ & $7.44(\mathrm{t}, 1 \mathrm{H}, J=8.8)$ & 1 & H-6 & & - - - \\
\hline $4 a$ & 108.75 & & 0 & & & $\mathrm{H}-8$ \\
\hline 8 & 107.26 & 7.198(s,1H) & 1 & & H-2" & -- \\
\hline 5 & 102.48 & $7.80(\mathrm{~s}, 1 \mathrm{H})$ & 1 & & $\mathrm{H}-1 ", 7 "$ & -- \\
\hline $1 "$ & 67.11 & $4.18(\mathrm{t}, 2 \mathrm{H}, J=6.4)$ & 2 & H-3" & H-5 & H-3",4" \\
\hline $6 "$ & 66.15 & $3.59(\mathrm{t}, 4 \mathrm{H}, J=4.4)$ & 2 & H-5" & & - - - \\
\hline $2 "$ & 55.83 & $3.94(\mathrm{~s}, 3 \mathrm{H})$ & 3 & & $\mathrm{H}-8$ & - - - \\
\hline $4 "$ & 54.93 & $2.48(\mathrm{t}, 2 \mathrm{H}, J=6.4)$ & 2 & H-3" & & $\mathrm{H}-1 ", 3 "$ \\
\hline $5 "$ & 53.41 & 2.39(br.s,4H) & 2 & H-6" & & H-4” \\
\hline $3 "$ & 25.84 & $2.00(\mathrm{~m}, 2 \mathrm{H}, J=6.4)$ & 2 & $\mathrm{H}-1 ", 4 "$ & & $\mathrm{H}-1 ", 4 "$ \\
\hline $7 "$ & & $9.54(\mathrm{~s}, 1 \mathrm{H})$ & & & $\mathrm{H}-5$ & \\
\hline
\end{tabular}

Sequence is made according to the chemical shift values of carbon atoms. $\delta$ ppm in DMSO-d $d_{6} \mathrm{~J}$ in $\mathrm{Hz}$ *Number in DEPT is thenumber of attachedprotons 


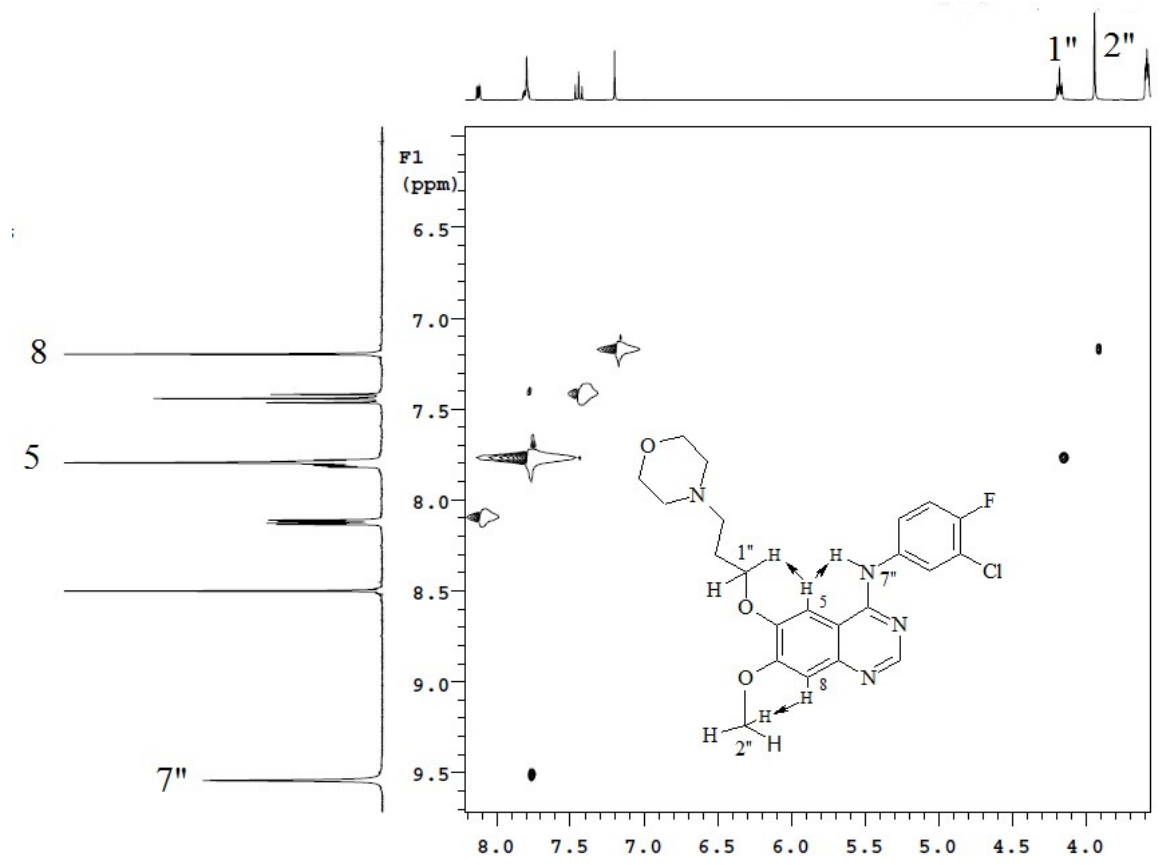

Figure 4. ROESY spectrum of Gefitinib in DMSO- $d_{6}$

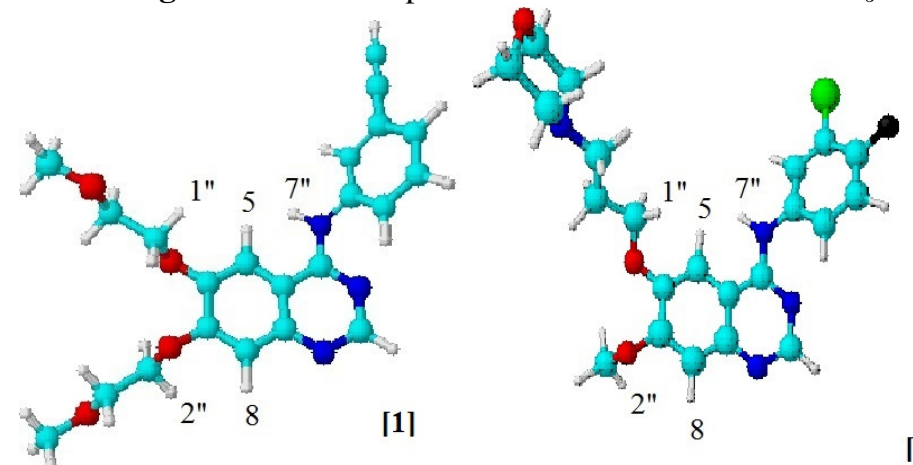

[2]

Figure 5. 3D Conformation of Erlotinib [1] andGefitinib [2] and NOE effect samong the H-1" : H-5 : H-7" and H-2" : H-8 protons

Neighbour protons of the side substituents of Erlotinib $\mathrm{HCl}$ and Gefitinib have been determined by their COSY spectra in DMSO- $d_{6}$. The best COSY spectrum was obtained in $\mathrm{CD}_{3} \mathrm{COCD}_{3}$ for Erlotinib, since the aliphatic protons were well seperated from each other, however acetone is not avaliable solvent for Erlotinib $\mathrm{HCl}$. The total assignments were made by a combination of one and two-dimensional NMR techniques. While the methine carbons were assigned from the HSQC spectra, the rest of other carbons were assigned from the HMBC spectra. Under normal HSQC conditions (One-Bond $\mathrm{J} 1 \mathrm{xh}=146$ ) it was not possible to see the expected contour at $\delta_{\mathrm{H}}=4.25$ and $\delta_{\mathrm{C}}=81.14$ for the acetylenic proton on C- 9" position of the Erlotinib. When the related value was increased to $250 \mathrm{~Hz}$, on the spectrometer, it is appeared well. 
As expected some differences were observed between the NMR spectra of the Erlotinib base and Erlotinib $\mathrm{HCl}$. In the NMR spectrum of Erlotinib $\mathrm{HCl}, 2-\mathrm{H}, 5-\mathrm{H}$ and $8-\mathrm{H}$ protons were shifted a little bit downfield area in DMSO- $d_{6}$. No significant changes were observed in the chemical shift values of the aromatic protons of anilino moiety between the Erlotinib base and $\mathrm{HCl}$ salt.

\section{Conclusion}

Total structural assignments of Erlotinib, Erlotinib $\mathrm{HCl}$ and Gefitinib have been achieved by using 2D-NMR experiments, including DEPT, COSY, ROESY, HSQC and HMBC. ROESY experiment gives the best important data for their structural elucidation.

\section{Acknowledgement}

Central Laboratory of Pharmacy Faculty of Ankara University provided support for the acquisition of the NMR and mass spectrometer used in this work. We thanks for providing Erlotinib $\mathrm{HCl}$ and Gefitinib to ATABAY Pharmaceuticals And Fine Chemicals Inc.

\section{References}

1. Dowell J, Minna J D, Kirkpatrick P, Nat Rev Drug Discov., 2005, 4(1), 13-14; DOI:10.1038/nrd1612

2. Barker A J, Gibson KH, Grundy W, GodfreyA A, Barlow J J, HealyM P, Woodburn J R, Ashton S E, Curry B J, Scarlett L, Henthorn L and Richards L, Bioorg Med Chem Lett., 2001, 11(14), 1911-1914; DOI:10.1016/S0960-894X(01)00344-4

3. Kobayashi K and Hagiwara K,Targ Oncol., 2013, 8(1), 27-33; DOI:10.1007/s11523013-0258-9

4. Fung C and Grandis J R, Expert Opin Emerg Drugs, 2010, 15(3), 355-373; DOI:10.1517/14728214.2010.497754

5. Hojjat-Farsangi M, Int J Mol Sci., 2014 , 15(8), 13768-13801; DOI:10.3390/ijms150813768

6. Norris T and, Santafianos D, J Chem Soc Perkin Trans., 2000, 2, 2498-2502; DOI:10.1039/B003531I

7. Nishino S, Hirotsu K, Shima H, Harada T and Oda H, US 2005/0130995 A1, Jun 16, 2005.

8. Chandregowda V, Rao G V and Reddy G C,Org Process Res Dev., 2007, 11(15), 813-816; DOI:10.1021/op700054p

9. Chandregowda V, Rao G V and Reddy G C, Synth Commun., 2007, 37(19), 34093415; DOI:10.1080/00397910701483761

10. Chandregowda V, Rao G V and Reddy G C, Heterocycles, 2007, 71(1), 39-48; DOI:10.3987/COM-06-10884

11. Kothakonda K K, Rey A W and Guntoori B R, WO 2010/040212 A1, April 15, 2010.

12. Prasad R J, Rao B N and Chowdary N V, US 7,960,545 B2, Jun 14, 2011.

13. Asgari D, Aghanejad A and Mojarrad J S, Bull Korean Chem Soc., 2011, 32(3), 909914; DOI:10.5012/bkcs.2011.32.3.909

14. Barghi L, Aghanejad A, Valizadeh H, Barar J and Asgari D, Adv Pharm Bull., 2012, 2(1), 119-122; DOI:10.5681/apb.2012.017

15. Nishino S, Hirotsu K, Shima H, Harada T and Oda H, EP 1481971 A1, Feb 6, 2003.

16. Sanmarti M B, Roses M L, Comely A C, Georges Y P. WO2011/076813, June 30, 2011.

17. Zhang $\mathrm{G}$ and Zha L, Res Chem Intermed., 2013, 39(6), 2303-2309;

DOI:10.1007/s11164-012-0757-9

18. Knesl P, Röseling D and Jordis U, Molecules, 2006, 11(4), 286-297; DOI: $10.3390 / 11040286$ 
19. Marzaro G, Guiotto A, Pastorini G and Chilin A, Tetrahedron, 2010, 66(4), 962-968; DOI:10.1016/j.tet.2009.11.091

20. Devasari N, Dora C P, Singh C, Paidi S R, Kumar V, Sobhia M E and Suresh S, Carbohydr Polym., 2015, 134, 547-556; DOI:10.1016/j.carbpol.2015.08.012

21. Zhang X, Lv X,WO 2015/188318 A1, December 17, 2015. 